Article

\title{
Assessing Threats and Conservation Status of Historical Centers of Oak Richness in California
}

\author{
Kelly Easterday ${ }^{1}$, Patrick J. Mclntyre ${ }^{2}$, James H. Thorne ${ }^{3}$, Maria J. Santos ${ }^{4}$ and Maggi Kelly $1,5,6, *$ \\ ${ }^{1}$ Department of Environmental Science and Policy, University of California Berkeley, Berkeley, CA 94720, USA; \\ E-Mails: kjeasterday@berkeley.edu (K.E.), maggi@berkeley.edu (M.K.) \\ 2 Biogeographic Data Branch, California Department of Fish and Wildlife, Sacramento, CA 95814, USA; \\ E-Mail: ptmcintyre@gmail.com \\ 3 Department Environmental Science and Policy, University of California Davis, Davis, CA 95616, USA; \\ E-Mail: jhthorne@ucdavis.edu \\ ${ }^{4}$ Copernicus Institute of Sustainable Development, Department of Innovation, Environmental and Energy Sciences, Faculty \\ of Geosciences, Utrecht University, 3508 TC Utrecht, The Netherlands; E-Mail: m.j.ferreiradossantos@uu.nl \\ ${ }^{5}$ University of California Division of Agriculture and Natural Resources, Davis, CA 95618, USA \\ ${ }^{6}$ Geospatial Innovation Facility, University of California Berkeley, Berkeley, CA 94720, USA \\ * Corresponding author
}

Submitted: 17 August 2016 | Accepted: 27 November 2016 | Published: 13 December 2016

\begin{abstract}
Oak trees are emblematic of California landscapes, they serve as keystone cultural and ecological species and as indicators of natural biological diversity. As historically undeveloped landscapes are increasingly converted to urban environments, endemic oak woodland extent is reduced, which underscores the importance of strategic placement and reintroduction of oaks and woodland landscape for the maintenance of biodiversity and reduction of habitat fragmentation. This paper investigated the effects of human urban development on oak species in California by first modeling historical patterns of richness for eight oak tree species using historical map and plot data from the California Vegetation Type Mapping (VTM) collection. We then examined spatial intersections between hot spots of historical oak richness and modern urban and conservation lands and found that impacts from development and conservation vary by both species and richness. Our findings suggest that the impact of urban development on oaks has been small within the areas of highest oak richness but that areas of highest oak richness are also poorly conserved. Third, we argue that current policy measures are inadequate to conserve oak woodlands and suggest regions to prioritize acquisition of conservation lands as well as examine urban regions where previous centers of oak richness were lost as potential frontiers for oak reintroduction. We argue that urban planning could benefit from the adoption of historical data and modern species distribution modelling techniques primarily used in natural resources and conservation fields to better locate hot spots of species richness, understand where habitats and species have been lost historically and use this evidence as incentive to recover what was lost and preserve what still exists. This adoption of historical data and modern techniques would then serve as a paradigm shift in the way Urban Planners recognize, quantify, and use landscape history in modern built environments.
\end{abstract}

\section{Keywords}

Quercus; species distribution models; urban planning; vegetation type mapping

\section{Issue}

This article is part of the issue "Paradigm Shifts in Urban Planning", edited by Matthias Drilling (University of Applied Sciences and Arts Northwestern Switzerland, Switzerland), Efrat Eizenberg (Israel Institute of Technology, Israel), Janet Stanley (University of Melbourne, Australia), Lee Boon Thong (Nilai University, Malaysia) and Andreas Wesener (Lincoln University Canterbury, New Zealand).

(C) 2016 by the authors; licensee Cogitatio (Lisbon, Portugal). This article is licensed under a Creative Commons Attribution 4.0 International License (CC BY). 


\section{Introduction}

Urban areas serve as important landscapes for a wide range of species. However, the rapid spread of urban development has heightened concern globally over potential losses in biodiversity and ecosystem services generated through landscape conversion. Sustainable planning initiatives in conjunction with ecological knowledge can help sustain biodiversity and reduce landscape fragmentation in urban environments. Calls for the integration of landscape ecology principles, natural resource conservation, and landscape history into urban planning has increased. In conjunction, the types of tools and data normally reserved for ecological analysis have begun to be used in the planning arena. The blending of principles from landscape ecology, urban planning data, and geospatial modelling tools represent a paradigm shift in the way we recognize, quantify, and use landscape history in planning our modern built environments. Current and future sustainable urban planning practices in both developed and undeveloped areas require detailed information on past landscapes. However, historical information is often spatially discontinuous and may require statistical extrapolation to fill in gaps and create regional descriptions. The use of species distribution modeling (SDM), also called environmental niche modeling (ENM), is common in the conservation and ecological restoration communities, but these tools have been underutilized in the urban planning arena. These models generate regional scale descriptions of past vegetation communities or taxa distributions, and may offer critical information in sustainable planning processes that want to reintroduce natural vegetation to already urbanized areas, or want avoid substantially altering the environment.

Oaks and oak woodlands are emblematic of California landscapes. They occupy about $13 \%$ of the state or 4 million ha in diverse canopy mixtures of eight primary tree species of the genus Quercus: coast live oak (Q. agrifolia), black oak (Q. kelloggii), valley oak (Q. lobata), blue oak (Q. douglasii), Oregon white oak (Q. garryana), Engelmann oak (Q. engelmannii), canyon live oak ( $Q$. chrysolepis), and interior live oak ( $Q$. wislizeni). Oak woodlands are defined by the presence of native oak species within a Mediterranean climate system (Pavlik, Muick, Johnson, \& Popper, 1991). In California, tree density and canopy cover varies widely, and woodland appearance ranges from open savanna with widely dispersed trees and understory dominated by Mediterranean annual grasses to dense oak dominated forests (Barbour, Keeler-Wolf, \& Schoenherr, 2007). These ecosystems play important roles for wildlife, insects, fungi and lichens (Grivet, Sork, Westfall, \& Davis, 2008) while the oaks themselves provide critical ecosystem services, their large canopies creating microclimates and regulating air quality and their root systems providing stability and water filtration (Marañón, Ibáñez, AnayaRomero, Muñoz-Rojas, \& Pérez-Ramos, 2012; Standiford \& Huntsinger, 2012). Oaks and oak woodlands are deeply rooted in California's history. Native Americans used and managed them extensively, deriving food and commodities from oak products (Anderson, 2005). Through the setting of seasonal fires Native Americans retained the quality of oak woodland habitat for game species while curbing pests and disease. Despite the cultural and ecological importance of oaks, the history and practice of converting oak woodlands is lengthy (Bartolome et al., 2002). Lower elevation woodlands, such as the valley oak woodlands of the fertile central valley, were converted to intensive agriculture while the woodlands in the surrounding foothills were historically used for extensive livestock grazing and fire wood production. Since the 1940 's it is estimated that California has lost 5,000 km² of oak woodland to three main drivers: development, range clearing, and agriculture (Gaman \& Firman, 2006, Kueppers, Snyder, Sloan, Zavaleta, \& Fulfrost, 2005; Pavlik et al., 1991). In this paper we focus on one of these drivers, urban development as $3,000 \mathrm{~km}^{2}$ ( one quarter) of the remaining oak woodlands is projected to be at risk of development before 2040.

California has one of the most rapidly growing human populations and this rate is accelerating (California Department of Finance, 2013; Medvitz \& Sokolow, 1995). Over $80 \%$ of hardwood lands in California are privately owned (California Fire and Resource Assessment Program, 2010), changing land use in the form of subdivisions has fostered expansion of the urbansuburban footprint (Huntsinger, Buttolph, \& Hopkinson, 1997; Huntsinger \& Fortmann, 1990). The urban interface with oak woodlands, once confined to the major population centers (San Francisco Bay, Sacramento, the Los Angeles basin), now extends throughout the entire state.

Historical ecologists have reconstructed historical distributions and landscapes by extracting mapped and textual data from archives using these products in planning urban and working landscapes (Beller, Downs, Grossinger, Orr, \& Salomon, 2015; Grossinger, Striplen, Askevold, Brewster, \& Beller, 2007). For example, photographs, maps, and data originally captured for purposes such as taxation or land surveying have become useful data sources in reconstructing historical vegetation conditions (Grossinger et al., 2007; Stein et al., 2010; Whipple, Grossinger, \& Davis, 2011). In addition to mining historical archives, detailed distribution maps of past vegetation conditions are predicted using species distribution modeling (Schussman, Geiger, Mau-Crimmins, \& Ward, 2006). SDMs are inferential models that develop relationships between species presence (and sometimes absence) and the key environmental variables that define an environmental niche, and use that relationship to map the niche across space (Graham, Ferrier, Huettman, Moritz, \& Peterson, 2004; Keenan, Maria Serra, Lloret, Ninyerola, \& Sabate, 2011; Peterson, 2011). The niche, often defined primarily with climatic variables, generates a probability surface of a species occurrence based on the ranges of the climatic variables where a species is 
known to exist and where those ranges exist in a given space. There are critiques related to these models (e.g. bias in time, assumption of climatic equilibrium, sensitivity to spatial scale); but they do serve regional goals. Given limited species locality information, these models help fill in the gaps of probable species occurrence and generate reasonable regional descriptions of a species distribution based on the input variables.

SDMs have traditionally been used in natural resource, conservation, and ecological fields to reconstruct historical habitats and examine climate change impacts (Kueppers et al., 2005; Schussman et al., 2006; Warren, Wright, Seifert, \& Shaffer, 2014), to map biotic invasions and disease spread (Kelly, Guo, Liu, \& Shaari, 2007; Václavík \& Meentemeyer, 2009), to examine bio-richness and speciation mechanisms (Graham et al., 2004; Rushton, Omerod, \& Kerby, 2004), and to inform conservation and species management priorities (Kelly, Fonseca, \& Whitfield, 2001; Raxworthy et al., 2003; Zhang et al., 2012). Yet their use in urban settings for planning remains limited (Milanovich, Peterman, Barrett, \& Hopton, 2012). In this paper, we argue that urban planning can benefit from a deeper understanding of past distributions of important landscape features, such as vegetation communities and key taxa; the use of historical data and species distribution modeling can aid in protection, guide in planning and management, and lend insight to future distributions given recent climate variability and landscape change.

In this paper, we use a digitized collection of historical vegetation data from a broad-scale California plant community survey from 1920-1930 to map historical oak tree species richness. We then use oak tree occurrence data to model oak richness across California focusing on eight dominant oak species (excluding data on shrub oaks and rare hybrid taxa); coast live oak (Q. agrifolia), black oak (Q. kelloggii), valley oak (Q. lobata), blue oak ( $Q$. douglasii), Oregon white oak (Q. garryana), Engelmann oak ( $Q$ engelmannii), canyon live oak (Q. chrysolepis), and interior live oak (Q. wislizenii). We present results in map form for individual species and as overlays conveying oak richness (historical oak "hot spots"). We then analyze how areas of historical oak richness (hot spots) juxtapose current patterns of urban lands and conservation areas and comment on potential opportunities for the reintroduction of lost habitat as well as current areas of potential protection. We use species richness, a known measure of biological diversity-to represent hot spots where several endemic species of oaks overlap. Historical oak richness or oak hot spots describe potential regional biodiversity hot spots that may represent ecological transition zones-areas where species range margins overlap-that constitute a favourable environment for species persistence or adaptation. Regional biodiversity hot spots-as defined in terms of numbers of species-are often conservation priorities that serve as a cost-effective way to preserve the greatest number of species. Using this historical dataset we are motivated by two questions: (1) where have areas of modeled historical oak richness been lost due to land conversion to urban uses; and (2) to what extent have conservation lands been able to preserve areas of historical oak richness.

\subsection{Historical Vegetation Data: The Vegetation Type Mapping Collection}

During the 1920 and 1930s, Vegetation Type Mapping (VTM) crews surveyed 16 million ha (40\%) of California's wildlands. They collected vegetation information at over 18,000 plots, produced detailed maps of dominant vegetation for over $100,000 \mathrm{~km}^{2}$, gathered over 23,000 herbarium specimens, and took over 3,000 photographs depicting California vegetation and landscapes (Colwell, 1977; Ertter, 2000; Kelly, Allen-Diaz, \& Kobzina, 2005; Kelly, Ueda, \& Allen-Diaz, 2008; Wieslander, 1935). The parts of the collection: maps, plot data and photographs have been used separately, primarily to investigate drivers of change, including climate and fire, and of changes in forest and chaparral communities around the state (Kelly et al., 2016). In this paper we use both the digitized georeferenced the plot data (Kelly et al., 2005; Kelly et al., 2008), and the digitized georeferenced polygons from the VTM vegetation maps (Thorne, Kelsey, Honig, \& Morgan, 2006; Thorne, Santos, \& Bjorkman, 2013) to develop distribution models for these oak species. We did not use the VTM georeferenced herbarium specimens to avoid potential duplication. To our knowledge this is the first effort to use both the maps and plot data in conjunction with modern species distribution modelling methods to create a comprehensive historical distribution of a taxa. This effort thereby increases the sample size of occurrence records usually gained from the use of georeferenced herbarium specimens alone.

\section{Methods}

\subsection{Historical Oak Data}

Location data for eight Quercus species was extracted from VTM using digitized vegetation maps and plot data (Kelly et al., 2005). The $\sim 18,000$ VTM plots although concentrated primarily along the Sierra Nevada mountain range and the central and southern coastal ranges (Figure 1) were surveyed across a gradient of vegetation types. The records contain data regarding tree stand structure (number per diameter class), percent cover of dominant vegetation by species, soil type, parent material, leaf litter, elevation, slope, aspect, parent material, and other environmental variables. The VTM vegetation map dataset consists of hand drawn polygons covering over $100,000 \mathrm{~km}^{2}$ in which species comprising $20 \%$ or greater of the visual cover of a stand were recorded.

We generated the oak species occurrences used for distribution modeling by obtaining the centroids of polygons in which oaks were recorded as a dominant species. 
a)

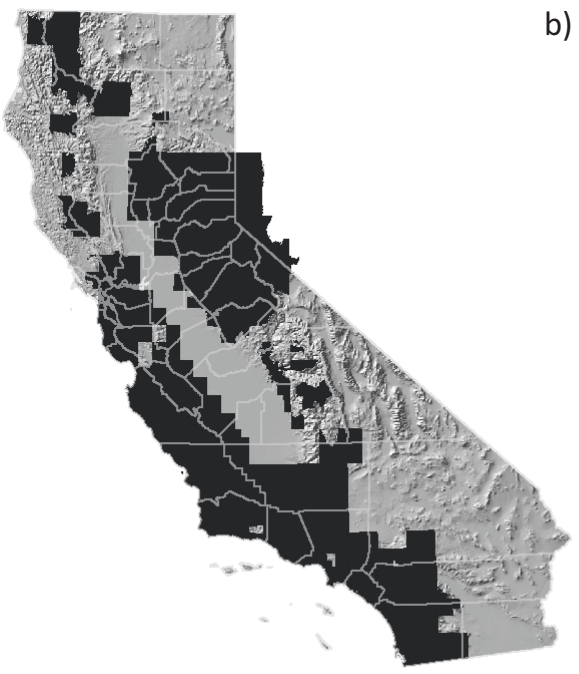

b)

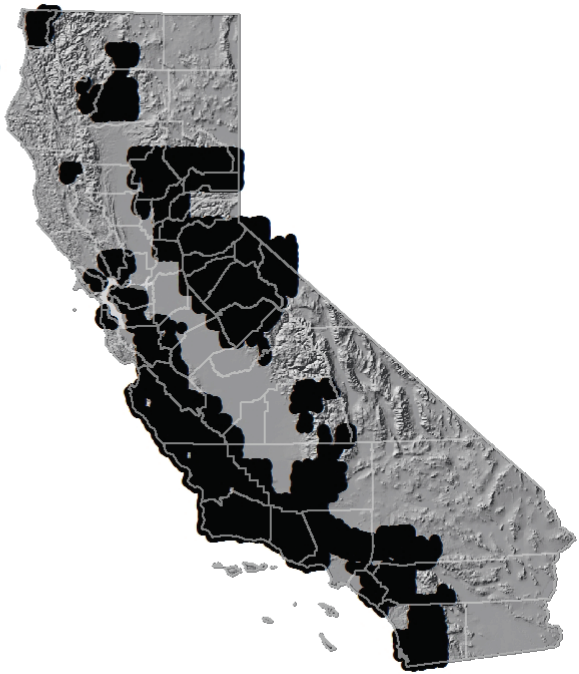

Figure 1. Locations of a) VTM vegetation maps and b) VTM vegetation plots in California.

Although the exact extent of the vegetation polygons maybe imprecise as they were hand drawn and distinguished through visual interpretation from nearby vantage points, the use of polygon centroid is likely to reduce the error in the overall sample from inexact locality placement. We removed duplicate localities from map and plot datasets for the same species. We then examined potential outliers and inconsistencies with visual and overlay methods (Hijmans, Schreuder, De la Cruz, \& Guarino, 1999). The total sample size for each species is listed in Table 1. It is important to note that these localities were confirmed presences of oak species and do not necessarily constitute the species entire range or environmental niche, the confirmed presences were limited in scope to the extent of the original VTM surveys which left out large portions of the Central Valley, North Coast, and Mojave. Additionally, the assembled occurrence data may underestimate potential occurrences within mixed stands due to the $20 \%$ cover threshold for reporting species. Despite the potential shortcomings of this dataset the VTM survey coverage is the most comprehensive and detailed historical survey of vegetation available for California.

\subsection{Distribution Modeling}

We use a reduced set of 30 year average (1960-1990) bioclimatic ("Bioclim") (Hijmans, Cameron, Parra, Jones, \& Jarvis, 2005) variables at $\sim 1 \mathrm{~km}$ spatial resolution to model the historical distribution of the eight oak species. These climatic variables are commonly used to model distributions based on specimens collected from across the $20^{\text {th }}$ century (e.g., including oaks. As this study did not involve predictions across multiple time periods, we opted to use the Bioclim data as it is the most widely used global climate dataset and has benefits in terms of replicability and access. To reduce problems associated with extensive collinearity of predictor variables we examine pairwise correlations among the 19 standard Bioclim variables across California and selected a single variable from pairs with a greater than 0.85 correlation coefficient (Pearson et al., 2006). We used 8 variables: mean diurnal temp range (Bio2), isothermality (Bio3), maximum temperature in the warmest month (Bio5), minimum temperature in the coldest month (Bio6), temperature annual range (Bio7), mean temperature in the wettest quarter (Bio8), annual precipitation (Bio12), and precipitation seasonality (Bio15).

Table 1. VTM dataset sample sizes used in species distribution modeling for eight California oak species.

\begin{tabular}{lllll}
\hline Species & Common name & Plot locality Records & Map locality records & Total \\
\hline Q. agrifolia & Coast Live Oak & 1,653 & 18,966 & 20,619 \\
Q. chrysolepis & Canyon Live Oak & 1,594 & 12,484 & 14,078 \\
Q. douglassii & Blue Oak & 1,732 & 14,826 & 16,558 \\
Q. engelmannii & Engelmann Oak & 61 & 555 & 616 \\
Q. garryana & Oregon White Oak & 169 & 952 & 1,121 \\
Q. kelloggii & California Black Oak & 3,126 & 13,413 & 16,539 \\
Q. lobata & Valley Oak & 601 & 3,777 & 4,378 \\
Q. wislizeni & Interior Live Oak & 2,677 & 9,356 & 12,033 \\
\hline & Total & 11,613 & 74,329 & 85,942 \\
\hline
\end{tabular}


We constructed and assessed the distribution models using Maxent v3.01 called from the R 3.03 statistical environment (R Development Core Team, 2013) using the Dismo package (Hijmans, Phillips, Leathwick, \& Elith, 2012). Background (pseudo-absence) data were generated by randomly sampling 10,000 points from the full area of VTM plot and map sampling (Figure 1). We used a k-fold sampling (with $k=4$ or $25 \%$ ) of the occurrence data for each oak species to partition the data into testing and training data, with each round of modeling containing $75 \%$ training and $25 \%$ testing data. We then assessed model fit using the AUC (area under curve) statistic, which evaluates the performance of model as a series of tradeoffs between true positives and false positives (Fielding \& Bell, 1997). AUC values range from 01 with a value of 0.5 representing a model with prediction probabilities close to random, and values greater than 0.5 signify a model with a greater power to predict areas of high suitability in locations of known species presence (Phillips, Anderson, \& Schapire, 2006). Using the AUC statistic, we confirmed how well the distribution predicted by our model matched the distribution from a sample of the historical occurrences. We used the maximum sensitivity plus specificity threshold to convert each modeled result from continuous probability scores (e.g. 0-100\%) to binary predicted/not-predicted scores (e.g. 0 and 1). This threshold has performed well in a recent evaluation of presence-only threshold methods (Liu, White, \& Newell, 2013). We then used this threshold to create individual surfaces that articulated the high probability range of each oak species given the climatic variables. Finally, we summed the eight binary predictions/surfaces for each species to generate a map of modeled historical oak richness for California. Historical oak richness or oak hot spots describes regions where there is spatial coincidence in the modeled ranges of individual oak species. Since these models are based on climatic variables alone the modeled areas of oak richness represent areas of historical climate that were highly suitable for an overlapping number of oak species. Low historical oak richness is represented as single species of oak, moderate represents $2-5$ overlapping species ranges, and high represents 6 or more overlapping species ranges.

\subsection{Areas of Oak Threat and Conservation}

We examined modeled hot spots of historical oak richness as they juxtapose with current urban areas and with protected areas in California using an overlay analysis of the binary maps of modeled historical oak species distributions and statewide spatial layers depicting current urban and protected areas. We used two current statewide products that depict urban footprints and protected areas. The urban footprint, derived from the 2010 decennial census, is useful for analyzing urban growth and associated impacts (U.S. Census Bureau, 2014). The California Protected Areas Database (CPAD, 2013) database tracks public, conservation and trust land ownership representing the most complete publicly available representation of landownership for the state of California. Both were provided by the U.S. government data portal: http://www.data.gov.

\section{Results}

Species distribution model support (AUC) ranged from 0.83 for $Q$. chrysolepis to 0.98 for $Q$. engelmannii (Table 2). The mapped binary results for individual oak species are shown in Figure 2, along with a statewide view of modeled historical oak richness. Areas of high historical oak richness (six or more oak species) include: a) the North Coast Ranges, b) the South Coast Ranges, c) the Sierra Foothill Belt, d) the Transverse Ranges including the Tehachapi Mountains, and e) the Peninsular Ranges (Figure 2).

We overlaid the map of modeled historical oak richness on the current urban footprint and the current conserved lands and found that impacts from development and conservation vary by species and richness. Impacts from urban development have been relatively small ( $\sim 5.5 \%$ of the land) within the areas of high oak richness (Table 3 ), however $17 \%$ of the historical distributions of individual oak species are found in current urban areas. Coast live oaks ( $Q$. agrifolia) and Engelmann oaks ( $Q$. engelmannii) are the most disproportionately affected; with $\sim 19 \%$ of each modeled range now under the modern urban footprint. Additionally, the ranges of valley oak ( $Q$. lobata), blue oak ( $Q$. douglasii), Oregon white oak ( $Q$. garryana) may be underrepresented in these models due to the lack VTM survey of coverage in these species normal ranges which include the Central Valley and the North Coast.

Areas of moderate historical oak richness (2-5 oak species) have some protection on conservation lands ranging from 27 to $39 \%$ of their predicted historical distribution. Four oak species have approximately half of their modeled historical range on current protected lands (Q. chrysolepis, Q. garryana, Q. kelloggii, and Q. wislizeni).

Table 2. AUC values from each species distribution model of eight California oak species, and threshold values using the Maximum Sensitivity and Specificity method for binary predictions of presence and absence.

\begin{tabular}{lll}
\hline Species & $\begin{array}{l}\text { Area Under } \\
\text { Curve (AUC) }\end{array}$ & $\begin{array}{l}\text { Maximum Sensitivity } \\
\text { + Specificity Threshold }\end{array}$ \\
\hline Q. agrifolia & 0.887 & 0.42 \\
Q. chrysolepis & 0.831 & 0.43 \\
Q. douglassii & 0.842 & 0.48 \\
Q. engelmannii & 0.987 & 0.17 \\
Q. garryana & 0.947 & 0.33 \\
Q. kelloggii & 0.869 & 0.44 \\
Q. lobata & 0.865 & 0.42 \\
Q. wislizeni & 0.853 & 0.45 \\
\hline
\end{tabular}




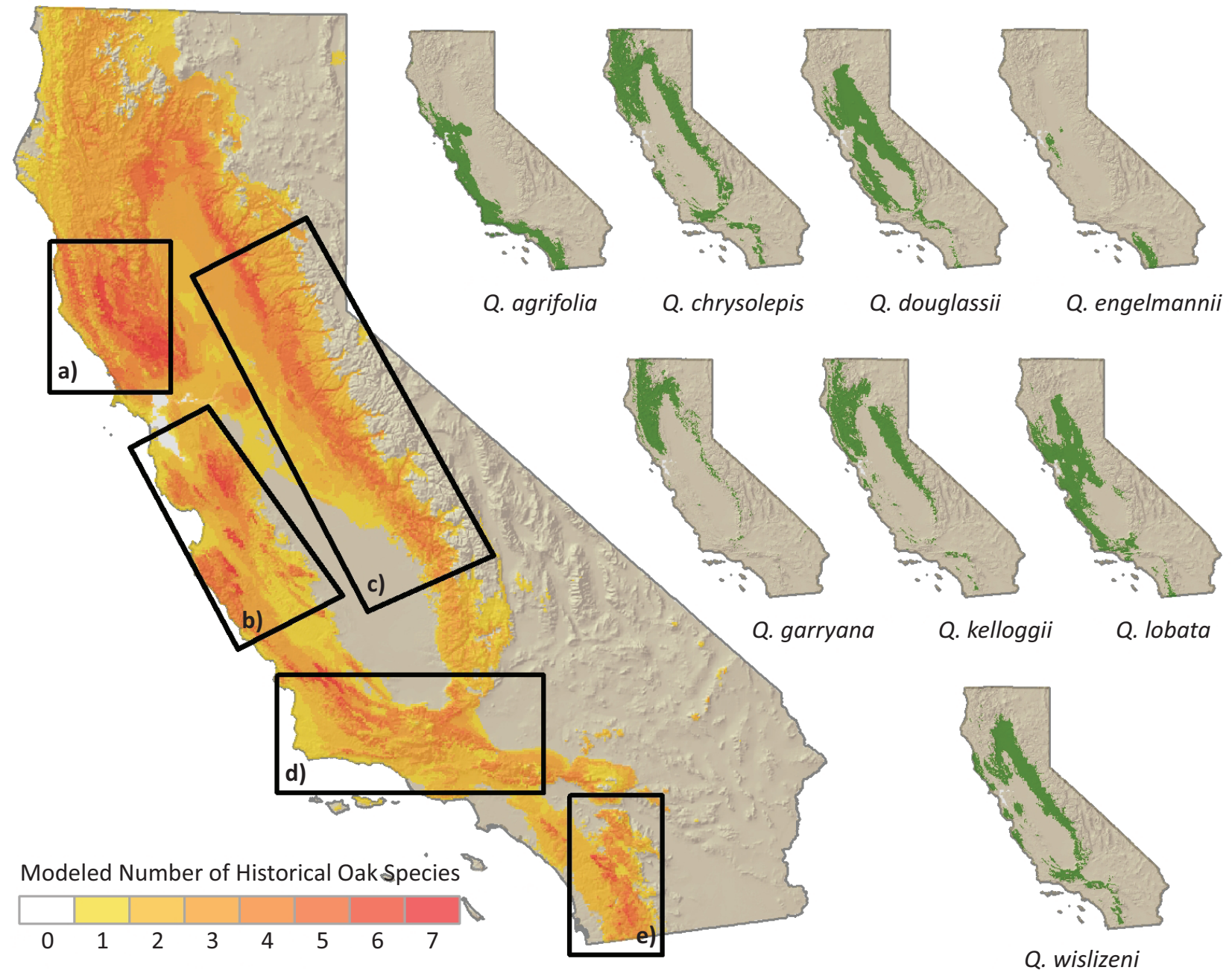

Figure 2. Modeled Number of Historical Oak Species: a) North Coast Range, b) South Central Coast Range, c) Sierra Nevada Foothills, d) Transverse Ranges including the Tehachapi Mountains, and e) Peninsular Ranges. Individual binary maps of eight modeled oak distributions are also shown.

However, hot spots of historical oak richness (6 or more oak species) currently have low representation in conserved lands. Of the mapped areas identified as supporting suitable habitat for seven oak taxa: $4 \%$ fall within areas developed since 1930, and $13 \%$ fall within lands with current conservation protection. For the conservation of high oak richness these regions would be high priority areas for conservation land acquisition.

A visual comparison of areas of modeled historical oak distribution with urban areas and parks, public, conservation and trust ownership lands is found in Figure 3. We focus on three urbanizing areas of the state: a) the San Francisco Bay Area, b) the Sacramento/Sierra Foothills area, and the c) Los Angeles area; as well as two areas that have high richness and recent conservation: d) the inner Coast Ranges of Napa and Lake Counties, and e) the Tehachapi Mountains. Despite the fact that current urban areas do not occur in areas of high historical oak richness, there is considerable spatial juxtaposition of current urban footprint and areas of mod- erate historical oak richness (2-5 species) in large urban areas across the state. In the San Francisco Bay Area (Figure $3 a$ ), a $3,490 \mathrm{~km}^{2}$ region covering ten counties, 918 $\mathrm{km}^{2}(26.3 \%)$ of single species range, $2,556 \mathrm{~km}^{2}$ (73.3\%) of moderate species richness (2-5 oak species), and $10 \mathrm{~km}^{2}$ $(0.3 \%)$ of Quercus hot spots have been converted to urban areas. This region of the state is a matrix of intermixed parkland and urban area: the cities of Contra Costa and Alameda on the east side of the San Francisco Bay area surrounding and encroaching on the biologically rich area of Mt. Diablo, although some of this land is protected in public, conservation and land trust lands. In the southern San Francisco Bay area, the rapid expansion between the San Jose urban area and Morgan Hill is encroaching on an area rich in oak species richness.

In the Sacramento and Sierra Foothills area (Figure $3 \mathrm{~b})$, a $1,630 \mathrm{~km}^{2}$ region covering five counties, $241 \mathrm{~km}^{2}(14.8 \%)$ of single species range, $1,293 \mathrm{~km}^{2}$ (79.3\%) of moderate species (2-5 oak species) richness, and $2.9 \mathrm{~km}^{2}(0.2 \%)$ of Quercus hot spots have been con- 
Table 3. Modeled Historical Oak Richness. Area supporting oaks predicted to occur based on species distribution models, by number of oak tree species richness and individual oak species, and the percentage found within urban or protected areas.

\begin{tabular}{|c|c|c|c|c|}
\hline Species & Total km² & \multicolumn{2}{|c|}{$\%$ in Urbanized Areas } & $\%$ in Protected Areas \\
\hline Q. agrifolia & $58,597.8$ & \multicolumn{2}{|r|}{18.62} & 26.61 \\
\hline Q. chrysolepis & $88,543.9$ & \multicolumn{2}{|r|}{0.92} & 54.88 \\
\hline Q. douglassii & $83,423.5$ & \multicolumn{2}{|r|}{5.07} & 17.18 \\
\hline Q. engelmannii & $9,373.6$ & \multicolumn{2}{|r|}{18.99} & 32.49 \\
\hline Q. garryana & $43,882.6$ & \multicolumn{2}{|r|}{0.75} & 50.18 \\
\hline Q. kelloggii & $68,182.2$ & \multicolumn{2}{|r|}{1.57} & 47.25 \\
\hline Q. lobata & $76,616.5$ & \multicolumn{2}{|r|}{8.27} & 19.50 \\
\hline Q. wislizeni & $46,606.0$ & \multicolumn{2}{|r|}{4.42} & 51.80 \\
\hline Number of Species & Description & Total km² & $\%$ in Urbanized Areas & $\%$ in Protected Areas \\
\hline 1 & \multirow{2}{*}{ Low } & $39,775.7$ & 16.86 & 32.91 \\
\hline 2 & & $59,748.6$ & 7.57 & 32.85 \\
\hline 3 & \multirow{3}{*}{ Moderate } & $62,484.7$ & 4.02 & 38.57 \\
\hline 4 & & $20,924.4$ & 3.03 & 39.35 \\
\hline 5 & & $9,114.3$ & 2.66 & 27.81 \\
\hline 6 & \multirow{2}{*}{ High } & $2,533.2$ & 1.45 & 24.66 \\
\hline 7 & & 959.5 & 4.03 & 13.11 \\
\hline
\end{tabular}

verted to urban areas. The Sierra Foothills are a rich area for oak species, and are increasingly threatened with urban and exurban expansion: particularly along the Interstate 80 and Highway 50, shown as the twin arms of urbanization located east from the city of Sacramento in Figure $3 b$. There are few large parks or open space lands in this Foothill Belt (150-900 $\mathrm{m}$ in elevation) to help conserve oak richness: most federally owned lands in the Sierra Nevada are located in the mixed Conifer belt and higher (above $900 \mathrm{~m}$ ). In both of these areas urban expansion has affected the moderate (2-5 oak species) richness class the most.

In the Los Angeles area (Figure 3c), a 9,169 $\mathrm{km}^{2}$ region covering five counties, $4,219 \mathrm{~km}^{2}(46.0 \%)$ of single species range, $1,113 \mathrm{~km}^{2}(12.1 \%)$ of moderate species (2-5 oak species) richness have been converted to urban areas. No high Quercus richness areas were converted to urban areas. Oak habitat extends south from the Transverse Ranges and rings the mountains surrounding the Los Angeles Basin (Fig. 3c) and Peninsular Ranges to the border with Mexico. This is an area of active urban growth; however, there are considerable large extant open space areas (primarily federal lands) to serve as preserves.

The inner Coast Ranges of Napa and Lake Counties in northern California (Figure $3 \mathrm{~d}$ ) and the Tehachapi mountains of southern California (Figure 3e) are areas of high oak richness that have recently significantly increased their conservation of oak diversity. In 2015 the area identified with high oak richness in Napa and Lake counties was proclaimed as a new National Monument (Berryessa Snow Mountain) and in 2010 the purchase of 62,000 acres of Tejon Ranch, located in the Techachapis was approved.

\section{Discussion}

Reconstructing historical distributions and patterns of richness is critical to understanding the current landscape, how it functions, as well as to provide for thoughtful and informed management, protection, restoration, and planning decisions (Rhemtulla \& Mladenoff, 2007). The history of a landscape or the historical distribution of a species does not establish a linear path for the future, but rather, provides a foundation of understanding (White \& Walker, 1997), and gives context to the trajectories of species and landscapes (Foster et al., 2003). Urban planning principles urge the integration of elements from the surrounding flora, fauna, and topography in building sustainable landscapes (McHarg, 1971; Steiner, 2008). Therefore, integrating historical landscape ecological research with disciplines that investigate and modify the built environment such as planning provides a pathway for directing future landscape change. Understanding and mapping historical distributions of natural vegetation types, as well as using historical data in modern modeling provides opportunity for ecologically and historically based decision making, planning, and policy direction. As human population increases, planning projects increasingly modify current infrastructure and existing structures. Therefore, knowledge of past landscape history could provide critical inspiration for regreening cities and re-connecting them with their past. Many of California's urban areas were constructed in landscapes historically rich in oak woodlands: this disappearance of oaks within the urban landscape has since motivated plans to return oaks even within heavily urbanized areas (Grossinger et al., 2007; Whipple et al., 2011). The utility of historical data to drive environmental niche 

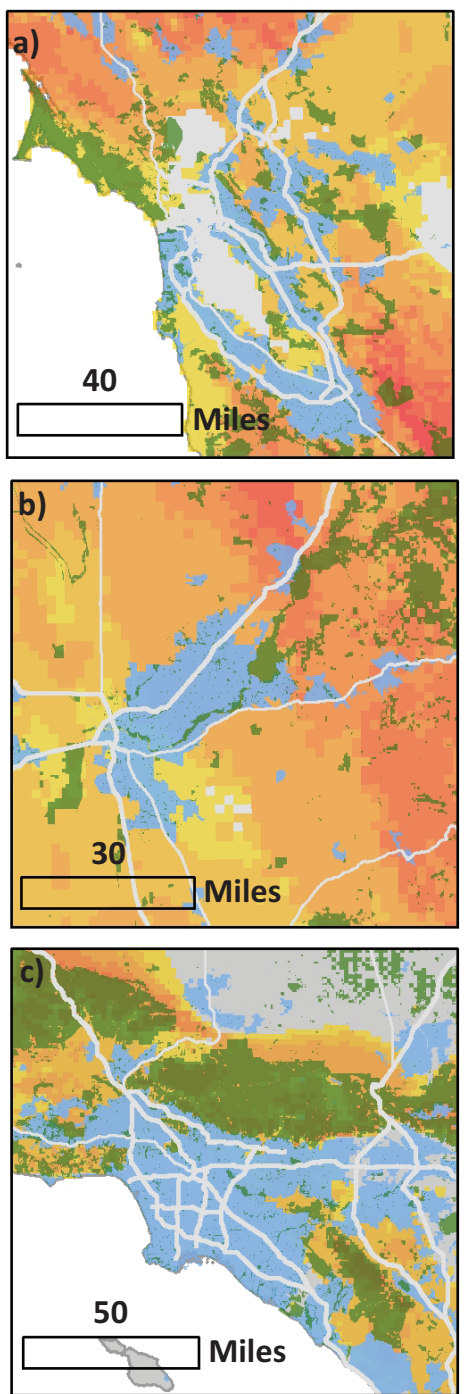

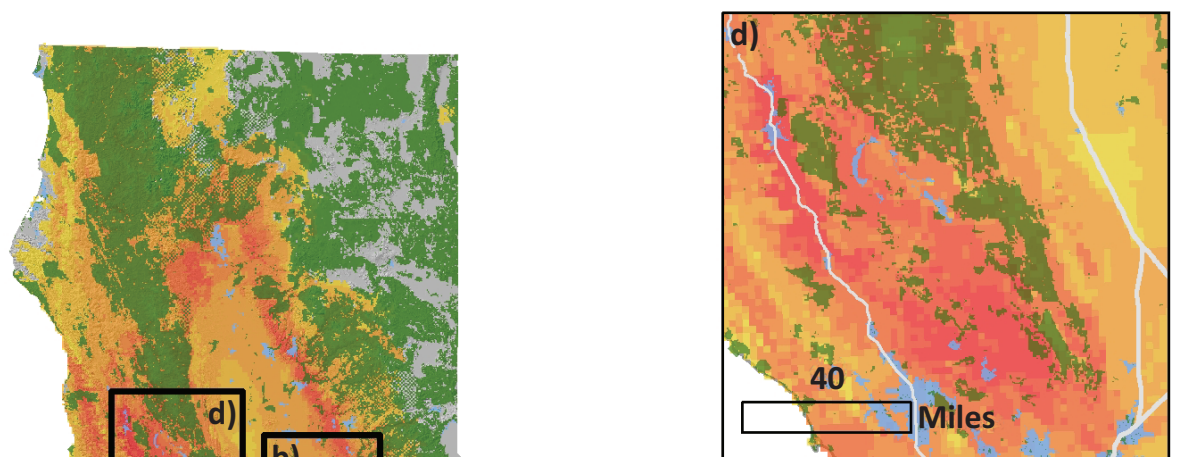

Highways

Interstate

Other

Open Space and Parks

Urban Areas

\begin{tabular}{|l|l|l|}
\hline Modeled Number of Historical Oak Species \\
\hline
\end{tabular}

$$
\begin{array}{llllllll}
0 & 1 & 2 & 3 & 4 & 5 & 6 & 7
\end{array}
$$

Figure 3. Areas of historical Quercus richness mapped with current urban and protected areas, with a focus on juxtaposition of historical oak richness and urban areas: a) San Francisco Bay Area, b) Sacramento/Sierra Foothills, c) Los Angeles; as well as areas where historical oak richness are not near protected areas: d) Napa/Sonoma/Mendocino Counties and e) Tehachapi mountains.

models, generating past species distributions and reconstructions of vegetation communities is an unexplored theme in urban planning. This study of using a single historical dataset (VTM) to provide historical distributions of one taxa is just one example of the capabilities and value added information that rich biogeographic data can lend to urban planning. We argue that the lack understanding of past landscapes and important vegetation communities is a potential oversight within urban planning that is easily remedied through the use of the techniques and data presented in this paper and strengthened with other rich biogeographic datasets available for the state (see Table 4). By linking the past with the present through the use of modeling techniques we carry invaluable ecosystem and human health services into our modern urban environments.
Through the development of environmental niche models, we have found that California oaks have been greatly impacted by urban development and this is likely to continue. Historical land use change, such as widespread clearing of blue oaks during "rangeland improvement" programs (Bolsinger, 1988), and current and future loss of habitat for urban and ex-urban expansion, will further fragment intact oak woodlands, eroding the sustainability of the oak woodland ecosystem and its associated products and ecological services, including wildlife habitat provision (Hilty \& Merenlender, 2004), genetic richness, and evolutionary potential (Grivet et al., 2008). The Sierra Foothills region (Figure 2c) of the state is an example of these complicated interactions with urban and suburban growth predicted to double by 2020 at great consequence to forests and rangelands (Theobald, 
Table 4. List of the most comprehensive biodiversity databases for California with reference to the type of data they hold, the number of specimens reported at the time (11/2016) and their extent. These databases provide historical and current species occurrence information that can be used to construct species distribution models. Note that some records are redundant, and may be housed in multiple databases.

\begin{tabular}{|c|c|c|c|}
\hline Database & Data & $\begin{array}{l}\text { Number of } \\
\text { specimens/localities }\end{array}$ & Extent \\
\hline $\begin{array}{l}\text { Global Biodiversity Information Facility (GBIF) } \\
\text { http://www.gbif.org }\end{array}$ & Plants and Animals & $624,423,832$ & Global \\
\hline $\begin{array}{l}\text { California Natural Diversity Database (CNDDB) } \\
\text { https://www.wildlife.ca.gov/Data/CNDDB }\end{array}$ & $\begin{array}{l}\text { Plants and Animals- } \\
\text { rare species only }\end{array}$ & 86,000 & California \\
\hline $\begin{array}{l}\text { HOLOS-Berkeley Ecoinformatics Engine* } \\
\text { https://holos.berkeley.edu }\end{array}$ & Plants, Animals, Maps & $>3$ million & $\begin{array}{l}\text { Primarily } \\
\text { California }\end{array}$ \\
\hline $\begin{array}{l}\text { GAP } \\
\text { http://gapanalysis.usgs.gov/species }\end{array}$ & Animals only & 1,480 species & United States \\
\hline $\begin{array}{l}\text { Vertnet } \\
\text { http://vertnet.org }\end{array}$ & Animals only & 80 million & Global \\
\hline $\begin{array}{l}\text { Biodiversity Information Serving Our Nation (BISON) } \\
\text { https://bison.usgs.gov }\end{array}$ & Plants and Animals & $>100$ million & United States \\
\hline $\begin{array}{l}\text { INaturalist } \\
\text { http://www.inaturalist.org }\end{array}$ & Plants and Animals & $3,173,095$ & Global \\
\hline $\begin{array}{l}\text { CalFlora } \\
\text { https://www.calflora.org }\end{array}$ & Plants only & $>1$ million & California \\
\hline $\begin{array}{l}\text { Consortium of California Herbaria (CCH) } \\
\text { http://ucjeps.berkeley.edu/consortium }\end{array}$ & Plants only & $>2$ million & $\begin{array}{l}\text { Primarily } \\
\text { California }\end{array}$ \\
\hline $\begin{array}{l}\text { iDigBio } \\
\text { https://www.idigbio.org }\end{array}$ & Plants and Animals & $73,192,805$ & Global \\
\hline
\end{tabular}

* locality information used in this paper was sourced from HOLOS-Berkeley Ecoinformatics Engine

2005). Urban growth in this area has extended into rural areas through rapid development of low density housing, increasing competing interests in the urban/wildlife interface, challenging fire management in these arid ecosystems, and illustrating the complex relationship between natural resource management and urban development encountered across the state (Byrd, Rissman, \& Merenlender, 2009). Historical species richness and distribution data such as presented may serve to highlight areas where developmental pressures are encroaching upon high oak richness, prompting further investigation.

Oaks in particular, are emblematic of California landscapes and serve as keystone cultural and ecological species providing ecosystem services through the provisioning of shade, soil stabilization, air and water quality regulation, food and shelter for animals, as well as providing aesthetics linked to increased property value. As more historical landscapes are being lost to increased urbanization and climatic pressures are projected to reduce species ranges (Kueppers et al., 2005), it is critical to maintain species diversity and reduce habitat fragmentation by making our built and natural environments more cohesive through the strategic placement and reintroduction of important habitats and species, such as oaks. Through the use of historical data and modeling the integration of lost landscape features starts from a more informed position. Current efforts (e.g. Grossinger et al., 2007; Whipple et al., 2011) in the California Bay Area serve as an example of how coordinated efforts between local open space councils, local stewards, and urban planning officials can led to "re-oaking" (Grossinger et al., 2012, Grossinger \& Beller, 2011): the reintroduction of oak woodland landscapes and of native oaks to the urban forest canopy. Future efforts in urban planning would also benefit from the use of historical data and modeling to locate hot spots of species richness, understand where habitats and species have been lost historically, and use this evidence as incentive to recover what was lost and preserve what still exists.

Understanding past distributions as we have done in this paper is a critical step in the development of future models that address the impacts of a changing climate. Future climate models for California show trends of increasing temperatures, creating longer summers and shorter, warmer winters, with less snowpack retention and therefore a diminishing water source to last through the longer, drier summers (Cayan, Luers, Hanemann, \& Franco, 2006; Luers, Cayan, Franco, Hanemann, \& Croes, 
2006; Thorne, Boynton, Flint, \& Flint, 2015). Expected increasing temperatures will likely exacerbate existing ecological problems from pests and diseases (Cayan et al., 2006; Luers et al., 2006). Diseases such as Armillaria, Hypoxylon (root rot) and Phytophthora ramorum (commonly known as "sudden oak death") are expected to more easily infect drought-stressed trees (California Fire and Resource Assessment Program, 2010; Cayan et al., 2006; Luers et al., 2006). P. ramorum, which can rapidly kill coast live oak (Q. agrifolia) and California black oak (Q. kelloggii), among other species, has already been confirmed in 14 counties in the state of California (California Oak Mortality Task Force, n.d.).

Policy measures to protect oaks and oak woodlands might be a way to conserve areas of oak richness, but measures are complicated by the fact that the majority of oak-dominated woodlands in the state $(>80 \%)$ are located on private lands (Davis et al., 1998; Pavlik et al., 1991; Santos \& Thorne, 2010; Standiford \& Bartolome, 1997). Further, the notion of oak woodlands as a traditional working landscape historically reduced their value in the eyes of the conservation community possibly delaying formalized protection until the 1970's (Cox \& Underwood, 2011; Santos, Watt, \& Pincetl, 2014). However, following this formalization of protection, the decentralized structure to statewide conservation and protection of oak woodlands, including the lack of statewide information on patterns of oak distribution and richness, has left the responsibility to protect and regulate oaks unclear.

The environmental consequences of inconsistent policy may have detrimental effects on the distribution of oak woodland communities. Since many of the oak hot spots identified span administrative and county boundaries, the need for a statewide mandate and clear delegation of protection and regulation authority is essential in developing a regional approach to conservation of oaks and oak woodland habitat. Although local policies may be inconstant county to county, they are still critical to developing a multi-scalar approach to conservation of oaks from individuals to landscape. Local strategies of conservation such as land acquisition in the form of land trusts and conservation easements Merenlender, Huntsinger, Guthey, \& Fairfax, 2004) and open space designation, would benefit from the mapping of past, current, and future oak distribution and richness. For instance, areas of modeled historical oak richness - the North Coast Ranges, the South Coast Ranges, the Sierra Foothill Belt, the Transverse Ranges, and the Interior Coast Ranges are important repositories for plant species endemism (Grivet et al., 2008; Thorne, Viers, Price, \& Stoms, 2009), and are critical conservation areas for oak woodlands that could be looked at more closely for incorporation under conservation easements open space designations, or planning that incorporates oaks and woodland habitat into new communities. Making transparent the locations of hot spots of richness gives strength and reasoning to local initiatives and could potentially initiate consistent statewide policy.

\section{Conclusions}

In this paper, we combined modeled data from a historical dataset with modern data on urban and protected areas, to provide a base for understanding the pressure of development on the distribution and richness of oak species. Areas of modeled historical oak richness were compared to the current footprint of urban areas and current conserved lands. We found that about a fifth of the area that previously contained a single oak species in the past is now urban with nearly $20 \%$ of the modeled historical range of both coast live oaks and Engelmann oaks now under the modern urban footprint. Areas of moderate historical oak richness have some protection on conservation lands but have been disproportionally affected by urban areas. Four oak species ( $Q$. chrysolepis, Q. garryana, $Q$. kelloggii, and $Q$. wislizeni) are moderately protected, with around half of their modeled range currently on conservation lands. Hot spots of high oak richness (e.g. six Quercus species) currently have low proportional representation in conserved lands with only $13 \%$ of the modeled range within current conservation protection. Plans for protecting oak woodlands in California are complicated by policy, which can be local in scale, and fragmented with no uniting statewide mandate. Many of the areas of high historical oak richness span administrative boundaries, and thus are difficult to manage by policy measures alone. We therefore encourage the use of historical data to encourage and guide protection of these landscapes in the form of policy and regulations, and to help in planning for future urban greening efforts resurrecting oak habitat that sits waiting beneath modern sidewalks.

\section{Acknowledgements}

We would like to thank our funding sources: Jeremy Fried at the USDA Forest Service, Pacific Northwest Forest Inventory and Analysis, and Carol Dumuth at the USDA Forest Service Pacific Southwest Research Station; Hugh Safford, Region 5 UC Forest Service, and Grant 500-09037 from the California Energy Commission. We would also like to acknowledge several students and staff who helped with the VTM data digitization project: Tim Doherty, Amy Romanek, Ann Huber, Ken-ichi Ueda, Brian Thomas, Thuy N'goc Le, Andrew Holguin, Ryan Boynton, and Jacquelyn Bjorkman.

\section{Conflict of Interests}

The authors declare no conflict of interests.

\section{References}

Alvey, A. A. (2006). Promoting and preserving biodiversity in the urban forest. Urban Forestry and Urban Greening, 5(4), 195-201.

Anderson, K., (2005). Tending the wild: Native American 
knowledge and the management of California's natural resources. Oakland, CA: University of California Press.

Araújo, M. B. (2002). Biodiversity hotspots and zones of ecological transition. Conservation Biology, 16(6), 1662-1663.

Barbour, M., Keeler-Wolf, T., \& Schoenherr, A. A. (2007). Terrestrial vegetation of California. Oakland, CA: University of California Press.

Bartolome, J. W., McClaran, M. P., Allen-Diaz, B. H., Dunne, J., Ford, L. D., Standiford, R. B., . . Forero, L. C., (2002). Proceedings of the fifth symposium on oak woodlands: Oaks in California's changing landscapes (pp. 22-25), Albany, CA: Pacific Southwest Research Station, Forest Service, U.S. Department of Agriculture.

Beller, E., Downs, P., Grossinger, R., Orr, B., \& Salomon, M. (2015). From past patterns to future potential: using historical ecology to inform river restoration on an intermittent California river. Landscape Ecology, 31(3), 581-600. dx.doi:10.1007/s10980-015-0264-7

Bolsinger, C. L. (1988). The hardwoods of California's timberlands, woodlands, and savannas (Vol. 148). Albany, CA: Pacific Southwest Research Station, Forest Service, U.S. Department of Agriculture.

Buerki, S., Callmander, M. W., Bachman, S., Moat, J., Labat, J. N., \& Forest, F. (2015). Incorporating evolutionary history into conservation planning in biodiversity hotspots. Philosophical Transactions of the Royal Society B, 370(1662), 20140014.

Byrd, K. B., Rissman, A. R., \& Merenlender, A. M. (2009). Impacts of conservation easements for threat abatement and fire management in a rural oak woodland landscape. Landscape and Urban Planning, 92(2), 106-116.

California Department of Finance. (2013). Report P-1: State and County Population Projections by County, by Race/Ethnicity, and by Major Age Groups, 20102060 (by decade). Sacramento, CA: California Department of Finance.

California Fire and Resource Assessment Program. (2010). The changing California: Forest and range 2010 assessment. Sacramento, CA: California Department of Forestry and Fire Protection.

California Oak Mortality Task Force (n.d.). Retrieved from www.suddenoakdeath.org

California Protected Areas Database. (2013). CPAD Version 2013b. Oakland, CA: Greenlnfo Network. Retrieved from http://www.calands.org

Cavender-Bares, J., Gonzalez-Rodriguez, A., Pahlich, A., Koehler, K., \& Deacon, N. (2011). Phylogeography and climatic niche evolution in live oaks (Quercus series Virentes) from the tropics to the temperate zone. Journal of Biogeography, 38(5), 962-981.

Cayan, D., Luers, A. L., Hanemann, M., \& Franco, G. (2006). Scenarios of climate change in California: An overview. Sacramento, CA: California Climate Change Center.
Colwell, W. L. (1977). The status of vegetation mapping in California today. In M. G. Barbour \& J. Major (Eds.), Terrestrial vegetation of California. Sacramento, CA: John Wiley \& Sons.

Cooper, W. S. (1922). The broad-sclerophyll vegetation of California: An ecological study of the chaparral and its related communities (No. 319). Washington, DC: Carnegie Institution.

Cox, R. L., \& Underwood, E. C. (2011). The importance of conserving biodiversity outside of protected areas in Mediterranean ecosystems. PLoS One, 6(1), e14508.

Davis, F. W., Stoms, D. M., Hollander, A. D., Thomas, K. A., Stine, P. A., Odion, D., . . Warner, K. (1998). The California Gap Analysis Project-Final Report. Santa Barbara, CA: University of California, Santa Barbara.

Elith, J., \& Leathwick, J. R. (2009). Species distribution models: Ecological explanation and prediction across space and time. Annual Review of Ecology, Evolution, and Systematics, 40(1), 677-697.

Ertter, B. (2000). Our undiscovered heritage: Past and future prospects for species-level botanical inventory, Madroño, 47(4), 237-252.

Ferenc, M., Sedláček, O., \& Fuchs, R. (2014). How to improve urban greenspace for woodland birds: Site and local-scale determinants of bird species richness. Urban Ecosystems, 17(2), 625-640.

Fielding, A. H., \& Bell, J. F. (1997). A review of methods for the assessment of prediction errors in conservation presence/ absence models. Environmental Conservation, 24(1), 38-49

Foster, D., Swanson, F., Aber, J., Burke, I., Brokaw, N., Tilman, D., \& Knapp, A. (2003). The importance of land-use legacies to ecology and conservation. BioScience, 53(1), 77-88.

Gaman, T., \& Firman, J., (2006). Oaks 2040: The status and future of oaks in California. Oakland, CA: California Oak Foundation.

Gordon, A., Simondson, D., White, M., Moilanen, A., \& Bekessy, S. A. (2009). Integrating conservation planning and landuse planning in urban landscapes. Landscape and Urban Planning, 91(4), 183-194.

Graham, C. H., Ferrier, S., Huettman, F., Moritz, C., \& Peterson, A. T. (2004). New developments in museum-based informatics and applications in biodiversity analysis. Trends in Ecology and Evolution, 19(9), 497-503.

Grivet, D., Sork, V. L., Westfall, R. D., \& Davis, F. W. (2008). Conserving the evolutionary potential of California valley oak (Quercus lobata Née): A muiltivariate genetic approach to conservation planning. Molecular Ecology Notes, 17(1), 139-156.

Grossinger, R. M., Askevold, R. A., Beagle, J., Beller, E. E., Brewster, E., Gardner, S., . . Striplen, C. J. (2012). Napa Valley historical ecology atlas: Exploring a landscape of transformation and resilience. Berkeley, CA: University of California Press.

Grossinger, R., \& Beller, E. (2011). "Oak landscapes in the recent past." In L. R. Costello, B. W. Hagen, \& K. 
S. Jones (Eds.), Oaks in urban landscapes: Selection, preservation, and care (pp. 222-223). Davis, CA: UC Agriculture and Natural Resources.

Grossinger, R. M., Striplen, C. J., Askevold, R. A., Brewster, E., \& Beller, E. E. (2007) Historical landscape ecology of an urbanized California valley: Wetlands and woodlands in the Santa Clara Valley. Landscape Ecology, 22(1), 103-120.

Guillera-Arroita, G., Lahoz-Monfort, J. J., Elith, J., Gordon, A., Kujala, H., Lentini, P. E., . . Wintle, B. A. (2015). Is my species distribution model fit for purpose? Matching data and models to applications. Global Ecology and Biogeography, 24(3), 276-292.

Guisan, A., \& Thuiller, W. (2005). Predicting species distribution: Offering more than simple habitat models. Ecology Letters, 8(9), 993-1009.

Hampe, A. (2004). Bioclimate envelope models: what they detect and what they hide. Global Ecology and Biogeography, 13(5), 469-476.

Hijmans, R. J., Cameron, S. E., Parra, J. L., Jones, P. G., \& Jarvis, A. (2005). Very high resolution interpolated climate surfaces for global land areas. International Journal of Climatology, 25(15), 1965-1978.

Hijmans, R. J., Phillips, S., Leathwick, J., \& Elith, J. (2012). Dismo: Species distribution modeling. $R$ package version 0.7-17.

Hijmans, R. J., Schreuder, M., De la Cruz, J., \& Guarino, L. (1999). Using GIS to check co-ordinates of genebank accessions. Genetic Resources and Crop Evolution, 46(3), 291-296.

Hilty, J. A., \& Merenlender, A. M. (2004). Use of riparian corridors and vineyards by mammalian predators in Northern California. Conservation Biology, 18(1), 126-135.

Huntsinger, L., Buttolph, L., \& Hopkinson, P. (1997). Ownership and management changes on California hardwood rangelands: 1985 to 1992 . Journal of Range Management, 50(4), 423-430.

Huntsinger, L., \& Fortmann, L. P. (1990). California's privately owned oak woodlands: Owners, use, and management. Journal of Range Management, 43(2), 147-152.

Jepson, W. L. (1910). The silva of California (Vol. 2). The University Press.

Kark, S., Schneider, C. J., \& Smith, T. B. (2001). Biodiversity hotspots and beyond: The need for preserving environmental transitions. Trends in Ecology and Evolution, 16(8), 431.

Keenan, T., Maria Serra, J., Lloret, F., Ninyerola, M., \& Sabate, S. (2011). Predicting the future of forests in the Mediterranean under climate change, with niche-and process-based models: $\mathrm{CO} 2$ matters! Global Change Biology, 17(1), 565-579.

Kelly, M., Allen-Diaz, B., \& Kobzina, N. (2005). Digitization of a historic dataset: The Wieslander California vegetation type mapping project. Madroño, 52(3), 191-201.

Kelly, M., Easterday, K., Rapacciuolo, G., Koo M., Mcln- tyre, P., \& Thorne, J. (2016). Rescuing and sharing historic vegetation data for ecological analysis: The California Vegetation Type Mapping project. Biodiversity Informatics, 11, 40-62.

Kelly, M., Guo, Q., Liu, D., \& Shaari, D. (2007). Modeling the risk of a new invasive forest disease in the United States: An evaluation of five environmental niche models. Computers, Environment and Urban Systems, 31(6), 689-710.

Kelly, M., Ueda, K., \& Allen-Diaz, B. (2008). Considerations for ecological reconstruction of historic vegetation: Analysis of the spatial uncertainties in the California Vegetation Type Mapping dataset. Plant Ecology, 194(1), 37-49.

Kelly, N. M., Fonseca, M., \& Whitfield, P. (2001). Predictive mapping for management and conservation of seagrass beds in North Carolina. Aquatic Conservation: Marine and Freshwater Ecosystems, 11(6), 437-451.

Kueppers, L. M., Snyder, M. A., Sloan, L. C., Zavaleta, E. S., \& Fulfrost, B. (2005). Modeled regional climate change and California endemic oak ranges. Proceedings of the Academy of Sciences, 102(45), 1628116286.

Liu, C., White, M., \& Newell, G. (2013). Selecting thresholds for the prediction of species occurrence with presence-only data. Journal of Biogeography, 40(4), 778-789.

Luers, A. L., Cayan, D. R., Franco, G., Hanemann, M., \& Croes, B. (2006). Our changing climate: Assessing the risks to California. Sacramento, CA: California Climate Change Center.

Marañón, T., Ibáñez, B., Anaya-Romero, M., MuñozRojas, M., \& Pérez-Ramos, I. (2016). Oak Trees and woodlands providing ecosystem services in Southern Spain. In I. D. Rotherham, C. Handley, M. Agnoletti, \& T. Samojlik (Eds.), Trees Beyond the Wood conference proceedings (pp. 291-299). Sheffield, UK: Wildtrack.

Marcucci, D. J. (2000). Landscape history as a planning tool. Landscape and Urban Planning, 49(1-2), 67-81.

McHarg, I. L. (1971). Design with nature. Garden City, NY: Doubleday/Natural History Press.

Medail, F., \& Quezel, P. (1999). Biodiversity hotspots in the Mediterranean Basin: Setting global conservation priorities. Conservation Biology, 13(6), 1510-1513.

Medvitz, A. G., \& Sokolow, A. D. (1995). Population growth threatens agriculture, open space. California Agriculture, 49(6), 11-17.

Merenlender, A. M., Huntsinger, L., Guthey, G., \& Fairfax, S. K. (2004). Land trusts and conservation easements: Who is conserving what for whom? Conservation Biology, 18(1), 65-75.

Milanovich, J., Peterman, W., Barrett, K., \& Hopton, M. (2012). Do species distribution models predict species richness in urban and natural green spaces? A case study using amphibians. Landscape and Urban Planning, 107(4), 409-418. doi:10.1016/ 
j.landurbplan.2012.07.010

Myers, N., Mittermeier, R. A., Mittermeier, C. G., Da Fonseca, G. A., \& Kent, J. (2000). Biodiversity hotspots for conservation priorities. Nature, 403(6772), 853-858.

Nielsen, A. B., van den Bosch, M., Maruthaveeran, S., \& van den Bosch, C. K. (2014). Species richness in urban parks and its drivers: A review of empirical evidence. Urban Ecosystems, 17(1), 305-327.

Niemelä, J. (1999). Ecology and urban planning. Biodiversity \& Conservation, 8(1), 119-131.

Pavlik, B. M., Muick, P. C., Johnson, S. G., \& Popper, M. (1991). Oaks of California. Los Olivos, CA: Cachuma Press.

Pearson, R. G., \& Dawson, T. P. (2003). Predicting the impacts of climate change on the distribution of species: are bioclimate envelope models useful? Global Ecology and Biogeography, 12(5), 361-371.

Pearson, R. G., Thuiller, W., Araújo, M. B., Martinez-Meyer, E., Brotons, L., McClean, C., . . . Lees, D. C. (2006). Model-based uncertainty in species range prediction. Journal of Biogeography, 33(10), 1704-1711.

Peterson, A. T. (2011). Ecological niches and geographic distributions (MPB-49). Princeton, NJ: Princeton University Press.

Phillips, S. J., Anderson, R. P., \& Schapire, R. E. (2006). Maximum entropy modeling of species geographic distributions. Ecological Modeling, 190(3), 231-259.

R Development Core Team. (2013). R: A language and environment for statistical computing. Vienna, Austria: R Foundation for Statistical Computing.

Raxworthy, C. J., Martinez-Meyer, E., Horning, N., Nussbaum, R. A., Schneider, G. E., Ortega-Huerta, M. A., \& Peterson, A. T. (2003). Predicting distributions of known and unknown reptile species in Madagascar. Nature, 426(6968), 837-841.

Rhemtulla, J. M., \& Mladenoff, D. J. (2007). Why history matters in landscape ecology. Landscape Ecology, 22, 1-3.

Rissman, A. R., \& Butsic, V. (2011). Land trust defense and enforcement of conserved areas. Conservation Letters, 4(1), 31-37.

Rissman, A. R., Lozier, L., Comendant, T., Kareiva, P., Kiesecker, J. M., Shaw, M. R., \& Merenlender, A. M. (2007). Conservation easements: biodiversity protection and private use. Conservation Biology, 21(3), 709-718.

Rudd, H., Vala, J., \& Schaefer, V. (2002). Importance of backyard habitat in a comprehensive biodiversity conservation strategy: a connectivity analysis of urban green spaces. Restoration Ecology, 10(2), 368-375.

Rushton, S. P., Omerod, S. J., \& Kerby, G. (2004). New paradigms for modelling species distributions? Journal of Applied Ecology, 41(2), 193-200.

Santos, M. J., \& Thorne, J. H. (2010). Comparing culture and ecology: Conservation planning of oak woodlands in Mediterranean landscapes of Portugal and California. Environmental Conservation, 37(2), 155-168.

Santos, M. J., Watt, T., \& Pincetl, S. (2014). The push and pull of land use policy: Reconstructing 150 years of development and conservation land acquisition. PloS One, 9(7), e103489.

Schussman, H., Geiger, E., Mau-Crimmins, T., \& Ward, J. (2006). Spread and current potential distribution of an alien grass, Eragrostis lehmanniana Nees, in the Southwestern USA: Comparing historical data and ecological niche models. Diversity and Distributions, 12(5), 582-592.

Scott, T., \& Standiford, R. B. (2001). Value of oak woodlands and open space on private property values in Southern California. Investigación agraria. Sistemas y recursos forestales, 10(1), 137-15.

Seto, K. C., Fragkias, M., Güneralp, B., \& Reilly, M. K. (2011). A meta-analysis of global urban land expansion. PloS One, 6(8), e23777.

Standiford, R. B., \& Bartolome, J. (1997). The integrated hardwood range management program: Education and research as a conservation strategy (USDA Forest Serivce General Technical Report PSW-GTR-16). Albany, CA: Pacific Southwest Research Station, Forest Service, U.S. Department of Agriculture.

Standiford, R., \& Huntsinger, L. (2012). Valuing forestland environmental services: A case study for California's oak woodlands. Proceedings of the International Symposium of Forest Economics 2012 (ISFE2012) (pp. 273-281). Beijing, China.

Stein, E. D., Dark, S., Longcore, T., Grossinger, R., Hall, N., \& Beland, M. (2010). Historical ecology as a tool for assessing landscape change and informing wetland restoration priorities. Wetlands, 30(3), 589-601.

Steiner, F. (2008). The living landscape (2nd ed.). Washington, DC: Island Press.

Theobald, D. M. (2005). Landscape patterns of exurban growth in the USA from 1980 to 2020, Ecology and Society, 10(1), 32.

Thorne, J., Viers, J., Price, J., \& Stoms, D. (2009). Spatial patterns of endemic plants in California. Natural Areas Journal, 29(4), 344-366.

Thorne, J. H., Boynton, R. M., Flint, L. E., \& Flint., A. L. (2015). The magnitude and spatial patterns of historical and future hydrologic change in California's watersheds, Ecosphere, 6(2), 1-30.

Thorne, J. H., Kelsey, R., Honig, J., \& Morgan, B. (2006). The development of 70-year-old Wieslander vegetation type maps and an assessment of landscape change in the central Sierra Nevada (prepared for the California Energy Commission, Public Interest Energy Research). Davis, CA: University of California Davis.

Thorne, J. H., Santos, M. J., \& Bjorkman, J. H. (2013). Regional assessment of urban impacts on landcover and Open space finds a smart urban growth policy performs little better than business as usual. PloS One, 8(6), e65258.

U.S. Census Bureau (2014). National Geospatial Data As- 
set (NGDA) Urban Area.

Václavík, T., \& Meentemeyer, R. K. (2009). Invasive species distribution modeling (iSDM): Are absence data and dispersal constraints needed to predict actual distributions?. Ecological Modelling, 220(23), 3248-3258.

Waddell, K. L. \& Barrett, T. M. (2005). Oak woodlands and other hardwood forests of California, 1990s (PNWRB-245).

Warren, D. L., Wright, A. N., Seifert, S. N., \& Shaffer, H. B. (2014). Incorporating model complexity and spatial sampling bias into ecological niche models of climate change risks faced by 90 California vertebrate species of concern. Diversity and distributions, 20(3), 334-343.

Whipple, A. A., Grossinger, R. M., \& Davis, F. W. (2011). Shifting baselines in a California oak savanna: Nine- teenth century data to inform restoration scenarios. Restoration Ecology, 19(101), 88-101.

White, P. S., \& Walker, J. L. (1997). Approximating nature's variation: selecting and using reference information in restoration ecology. Restoration Ecology, 5(4), 338-349.

Wieslander, A. E. (1935). A vegetation type map of California. Madroño, 3(3), 140-144.

$\mathrm{Wu}$, J. J. (2008). Making the case for landscape ecology an effective approach to urban sustainability. Landscape Journal, 27(1), 41-50.

Zhang, M. G., Zhou, Z. K., Chen, W. Y., Slik, J. F., Cannon, C. H., \& Raes, N. (2012). Using species distribution modeling to improve conservation and land use planning of Yunnan, China. Biological Conservation, 153, 257-264.

\section{About the Authors}
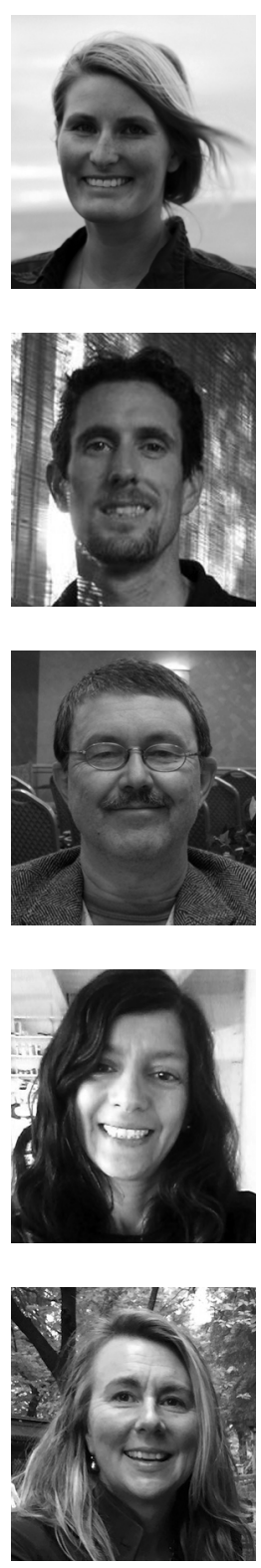

Kelly Easterday is a PhD candidate at University of California-Berkeley in the department of Environmental Science, Policy and Management. Her research focuses on understanding the intersection of anthropogenic and natural drivers of land use change and applying geospatial tools to inform policies and management strategies for threatened environments.

Patrick J. Mclntyre is a plant ecologist with the California Department of Fish and Wildlife interested in using biodiversity data to understand global change and inform conservation decision making.

James $\mathbf{H}$. Thorne is a landscape ecologist whose interests include biogeography, climate change adaptation, land use and translating science products into information that can be used in regional planning.

Maria J. Santos is an ecologist and conservation biologist interested in how land use and climate change affect ecosystems and species through space and time.

Maggi Kelly is Professor and Cooperative Extension Specialist based at UC Berkeley. Her lab's motto is "mapping for a changing California". She uses a range of techniques-remote sensing, object-based image analysis, geospatial modeling, lidar analysis, participatory webGIS and field methods-to answer applied questions about how and why California landscapes are changing, and what that change means for those who live on and manage our lands. 